\title{
PENGARUH BELANJA MODAL, PENDAPATAN ASLI DAERAH, DAN JUMLAH PENDUDUK TERHADAP PENDAPATAN PER KAPITA (STUDI EMPIRIS PADA PEMERINTAH DAERAH KABUPATEN/KOTA EKS KARESIDENAN SURAKARTA TAHUN 2013-2019)
}

\author{
Yuli Tri Cahyono ${ }^{1}$, Agnes Kumalasari ${ }^{2}$ \\ Muhammadiyah University of Surakarta ${ }^{1,2}$ \\ Email: ytc115@ums.ac.id
}

\begin{abstract}
Abstrak: Otonomi daerah merupakan hak, wewenang, dan kewajiban daerah otonomi untuk mengatur dan mengurus sendiri urusan pemerintah dan kepentingan masyarakat setempat sesuai dengan peraturan perundang-undangan dengan tujuan meningkatkan kesejahteraan dan pelayanan kepada masyarakat, pengembangan kehidupan berdemokrasi, keadilan, pemerataan, dan pemeliharaan hubungan yang serasi antara Pemerintah Pusat dan Pemerintah Daerah. Penelitian ini bertujuan untuk menguji pengaruh belanja modal, pendapatan asli daerah, dan jumlah penduduk terhadap pendapatan per kapita Kabupaten/Kota Eks Karesidenan Surakarta pada periode 20132019. Metode yang digunakan untuk pengambilan sampel yaitu sampel jenuh dan terpilih sebanyak 6 Kabupaten dan 1 Kota. Metode analisis yang digunakan adalah analisis regresi linier berganda yang dimaksudkan untuk mengetahui pengaruh belanja modal, pendapatan asli daerah, dan jumlah penduduk terhadap pendapatan per kapita. Analisis dilakukan dengan bantuan IBM SPSS Statistics 20. Hasil penelitian menunjukkan bahwa belanja modal, pendapatan asli daerah, dan jumlah penduduk secara statistik berpengaruh signifikan terhadap pendapatan per kapita.

Kata kunci: Belanja Modal, Pendapatan Asli Daerah, Jumlah Penduduk, Pendapatan
\end{abstract} Per Kapita

Indonesia merupakan negara yang terdiri atas wilayah yang luas serta memiliki banyak pulau, di mana setiap daerah memiliki potensi alam dan kebudayaan berbeda, sehingga perlu pengelolaan dan pemanfaatan yang maksimal untuk meningkatkan pembangunan di daerah masing-masing. Untuk meningkatkan pengelolaan dan pemanfaatan potensi daerah, pemerintah mengambil kebijakan memberikan kewenangan terhadap daerah untuk mengelola potensi yang ada di daerah terkait yang dikenal dengan istilah Otonomi Daerah (Otda).

Otda merupakan hak, wewenang, dan kewajiban daerah otonomi untuk mengatur dan mengurus sendiri urusan pemerintah dan kepentingan masyarakat setempat sesuai dengan peraturan perundangundangan. Otda diatur secara spesifik dalam Undang-Undang No. 33 tahun 2004 tentang Pemerintah Daerah. Dengan Otda, Pemerintah Daerah memiliki kewenangan untuk mengelola daerahnya sendiri tanpa bertentangan dengan kebijakan negara.

Pelaksanaan Otda di Indonesia merupakan kebijakan yang dipandang sangat demokratis dan memenuhi aspek desentralisasi yang sesungguhnya. Desentralisasi sendiri mempunyai tujuan untuk lebih meningkatkan kesejahteraan dan pelayanan kepada masyarakat, 
pengembangan kehidupan berdemokrasi, keadilan, pemerataan, dan pemeliharaan hubungan yang serasi antara Pemerintah Pusat dan Pemerintah Daerah. Kewenangan diberikan pada Pemerintah Daerah, kecuali untuk lima hal yang menjadi tanggung jawab Pemerintah Pusat, yaitu pembiayaan bagi politik luar negeri, pertahanan-keamanan, peradilan, pengelolaan moneter dan fiskal, agama, serta kewajiban pengembalian pinjaman kepada Pemerintah Pusat.

Untuk mendukung penyelenggaraan Otda diperlukan kewenangan yang luas, nyata, dan tanggung jawab secara proporsional yang diwujudkan dengan pengaturan, pembagian, dan pemanfaatan sumber daya nasional yang berkeadilan, serta perimbangan keuangan antara Pemerintah Pusat dan Pemerintah Daerah. Sumber pembiayaan Pemerintah Daerah dalam rangka perimbangan keuangan Pemerintah Pusat dan Daerah dilaksanakan atas dasar desentralisasi.

Menurut Badrudin (2011:99) Pendapatan Asli Daerah (PAD) merupakan pendapatan daerah yang bersumber dari hasil pajak daerah, hasil retribusi daerah, hasil pengelolaan kekayaan daerah yang dipisahkan, dan lain-lain yang bertujuan untuk menggali pendanaan dalam pelaksanaan Otda sebagai perwujudan asas desentralisasi.

Menurut Darise (2008:141) belanja modal merupakan pengeluaran yang dilakukan dalam rangka pembelian, pengadaan atau pembangunan aset tetap berwujud yang mempunyai nilai manfaat lebih dari dua belas bulan untuk digunakan dalam kegiatan pemerintahan, seperti dalam bentuk tanah, peralatan mesin, gedung dan bangunan, jalan, irigasi dan jaringan, dan aset tetap lainnya.

Menurut Subagiarta (2006:10) penduduk adalah semua orang yang berdomisili di wilayah geografis Indonesia selama enam bulan atau lebih mereka yang berdomisili kurang dari enam bulan tetapi bertujuan menetap. Pertumbuhan penduduk dipengaruhi oleh fertilitas, mortalitas, dan migrasi. Salah satu faktor yang menentukan keberhasilan pembangunan adalah pelaksanaan pembangunan itu sendiri, namun penduduk Indonesia menurut strukturnya berbeda dengan struktur negara yang lebih maju. Struktur penduduk Indonesia dikatakan masih muda, atau sebagian besar penduduk Indonesia berusia muda. Pada umumnya dalam suatu keluarga hanya ada satu yang bekerja berarti bahwa untuk setiap orang yang bekerja harus menanggung beban hidup dari anggota keluarga dari yang cukup besar. Semakin banyak orang yang harus ditanggung oleh setiap orang yang bekerja, maka semakin rendah kesejahteraan penduduk.

Menurut Mankiw (2006:221) pendapatan per kapita pada dasarnya mengukur kemampuan dari suatu daerah untuk memperbesar outputnya dalam laju yang lebih cepat dari pada tingkat pertumbuhan penduduknya. Tingkat dan laju pertumbuhan pendapatan per kapita sering digunakan untuk mengukur kemakmuran suatu daerah, yaitu seberapa banyak barang dan jasa yang tersedia bagi rata-rata penduduk untuk melakukan kegiatan konsumsi dan investasi. Selain itu, pendapatan per kapita juga 
merupakan ukuran yang digunakan untuk menggambarkan standar hidup (standard of living). Negara yang memiliki pendapatan per kapita yang tinggi umumnya memiliki standar hidup (standard of living) yang juga tinggi. Perbedaan pendapatan mencerminkan perbedaan kualitas hidup, negara kaya (dicerminkan oleh pendapatan per kapita yang tinggi) memiliki kualitas hidup yang lebih baik (dicerminkan oleh, antara lain, angka harapan hidup, tingkat kesehatan, dan tingkat pendidikan) dibandingkan dengan negara miskin.

Masniadi (2012) melakukan penelitian tentang faktor-faktor yang mempengaruhi tingkat pendapatan per kapita Indonesia tahun 1990-2008. Penelitian ini menggunakan alat analisis linier regresi berganda. Dari penelitiannya diperoleh hasil, bahwa jumlah penduduk dan tabungan berpengaruh signifikan terhadap pendapatan per kapita.

Sumardi (2015) melakukan penelitian tentang faktor-faktor yang mempengaruhi pendapatan per kapita dengan jumlah sampel sebanyak empat sampel yang berasal dari 9 kabupaten/kota di Provinsi Bali dari tahun 2008-2014. Penelitian ini menggunakan analisis regresi linier berganda. Dari penelitiannya diperoleh hasil, bahwa PAD, Dana Alokasi Umum (DAU), dan Dana Alokasi Khusus (DAK) memiliki pengaruh secara signifikan terhadap pendapatan per kapita.

Purba dan Silalahi (2019) melakukan penelitian tentang faktor-faktor yang mempengaruhi pendapatan per kapita pada Pemerintah Kabupaten/Kota Provinsi Riau dengan jumlah sampel sebanyak 60 sampel yang berasal dari 12 kabupaten/kota di Provinsi Riau dari tahun 2012-2016. Penelitian ini menggunakan analisis metode deskriptif. Dari penelitiannya diperoleh hasil, bahwa belanja modal, PAD, dan dana perimbangan berpengaruh signifikan terhadap pendapatan per kapita.

Berdasarkan latar belakang tersebut, tujuan yang ingin dicapai dalam penelitian ini adalah untuk mengetahui pengaruh belanja modal, PAD, dan jumlah penduduk terhadap pendapatan per kapita pada pemerintah daerah kabupaten/kota eks Karesidenan Surakarta tahun 2013-2019. Adapun hipotesis yang diajukan dalam penelitian ini adalah:

$\mathrm{H}_{1} \quad$ :Belanja modal berpengaruh terhadap pendapatan per kapita di

Kabupaten/Kota Eks Karesidenan Surakarta tahun 2013-2019.

$\mathrm{H}_{2} \quad$ :PAD berpengaruh terhadap pendapatan per kapita di Kabupaten/Kota Eks Karesidenan Surakarta tahun 2013-2019.

$\mathrm{H}_{3} \quad$ Jumlah penduduk berpengaruh terhadap pendapatan per kapita di

Kabupaten/Kota Eks Karesidenan Surakarta tahun 2013-2019. METODE

Menurut Sugiyono (2013:13) pendekatan kuantitatif adalah pendekatan yang digunakan untuk meneliti sampel atau populasi tertentu, dengan analisis data bersifat kuantitatif, dan pengumpulan data menggunakan instrumen yang bertujuan untuk menguji hipotesis. Data yang digunakan didapatkan dari kepustakaan (library research), yaitu berupa buku maupun laporan dari hasil penelitian terdahulu. Penelitian ini menggunakan pendekatan kuantitatif yang bertujuan untuk menguji pengaruh belanja modal, PAD, dan jumlah penduduk terhadap 
pendapatan per kapita Kabupaten/Kota Eks Karesidenan Surakarta tahun 2013-2019 dengan menggunakan data panel yang berupa gabungan antara data time series dan cross section dengan alat analisis regresi berganda (Ordinary Least Square/OLS).

Sampel dalam penelitian ini menggunakan metode sampel jenuh, yaitu teknik penentuan sampel yang mana semua anggota populasi digunakan sebagai sampel. Penelitian ini mengambil data dari Kabupaten/Kota Eks Karesidenan Surakarta yang berjumlah satu Kota dan enam Kabupaten tahun 2013-2019 (tujuh tahun) dengan sampel yang digunakan sebanyak 49 data.

Data dalam penelitian ini adalah data sekunder berupa bukti, catatan, atau laporan historis yang tersusun dalam arsip yang dipublikasikan maupun tidak dipublikasikan. Penulis memperoleh data belanja modal, PAD, dan jumlah penduduk dari situs web dan publikasi Badan Pusat Statistik (BPS).

Teknik analisis dalam penelitian ini adalah analisis kuantitatif dengan menggunakan program IBM SPSS Statistic 20. Analisis regresi linier berganda digunakan untuk menguji pengaruh belanja modal, PAD, dan jumlah penduduk terhadap pendapatan per kapita Kabupaten/Kota Eks Karesidenan Surakarta. Analisis data yang digunakan meliputi analisis deskriptif, uji asumsi klasik, analisis regresi, dan uji hipotesis.

\section{Analisis Deskriptif}

Menurut Ghozali (2011:19) analisis deskriptif adalah statistik yang digunakan untuk menganalisis data dengan cara memberikan gambaran atau mendeskripsikan data yang telah terkumpul yang dilihat dari nilai maksimum, minimum, rata-rata (mean), dan standar deviasi. Analisis ini merupakan teknik deskriptif yang hanya memberikan informasi tentang data yang dimiliki tanpa bermaksud membuat simpulan umum dan tidak bermaksud menguji hipotesis.

\section{Uji Asumsi Klasik}

Uji asumsi klasik digunakan untuk menghasilkan data yang akurat sehingga tidak terjadi bias. Uji asumsi klasik dalam penelitian ini meliputi uji normalitas, uji multikolinieritas, uji heteroskedastisitas, dan uji autokorelasi.

\section{a. Uji Normalitas}

Uji normalitas bertujuan untuk menguji apakah dalam model regresi terdapat variabel pengganggu atau residual memiliki distribusi normal. Uji normalitas dilakukan dengan uji Kolmogorov-Smirnov (K-S) yaitu dengan membandingkan antara nilai Asymp. Sig. dengan a $(0,05)$. Jika nilai Asymp. Sig. lebih besar dari a $(0,05)$, maka residual terdistribusi normal, dan sebaliknya jika nilai Asymp. Sig. lebih kecil dari a $(0,05)$, maka residual terdistribusi tidak normal.

\section{b. Uji Multikolinieritas}


Uji multikolinieritas bertujuan untuk menguji apakah dalam model regresi terdapat korelasi antar variabel independen yang dilakukan dengan uji Variance Inflation Factor (VIF). Pengujian dilakukan dengan membandingkan antara nilai VIF dengan skala 10. Jika nilai VIF lebih besar dari 10, maka terjadi multikolinieritas, dan sebaliknya jika nilai VIF lebih kecil dari 10, maka tidak terjadi multikolinieritas.

c. Uji Heteroskedastisitas

Uji heteroskedastisitas bertujuan menguji apakah dalam model regresi terjadi ketidaksamaan variance dari residual satu pengamatan ke pengamatan lain. Uji heteroskedastisitas digunakan untuk memastikan variance dalam penelitian ini bersifat tetap (homoskedastisitas), yang mana dilakukan dengan uji Glejser. Untuk mendeteksi terjadi atau tidaknya heteroskedastisitas dilakukan dengan menggunakan uji Glejser. Pengujian dengan uji Glejser dilakukan dengan membandingkan nilai Sig. dengan a $(0,05)$. Jika nilai Sig. lebih besar dari a $(0,05)$, maka tidak ada masalah heteroskedastisitas, dan sebaliknya jika nilai Sig. lebih kecil dari $\alpha(0,05)$, maka terdapat masalah heteroskedastisitas.

\section{d. Uji Autokorelasi}

Uji autokorelasi bertujuan untuk menguji apakah model regresi linier terdapat korelasi antara kesalahan pengganggu pada periode $\mathrm{t}$ dengan kesalahan pengganggu pada periode $\mathrm{t}-1$ (sebelumnya). Uji autokorelasi digunakan untuk memastikan model regresi bebas dari korelasi yang terjadi antara residual pada satu pengamatan dengan pengamatan lain, yang mana dilakukan dengan menggunakan uji Run Test. Pengujian dengan uji Run Test dilakukan dengan membandingkan nilai Asymp. Sig. dengan a $(0,05)$. Jika nilai Asymp. Sig. lebih besar dari a $(0,05)$, maka tidak terdapat autokorelasi, dan sebaliknya jika nilai Asymp. Sig. lebih kecil dari a $(0,05)$, maka terdapat autokorelasi.

\section{Analisis Regresi Linier Berganda}

Analisis regresi digunakan untuk mengetahui ketergantungan variabel dependen (terikat) dengan satu atau lebih variabel independen dengan tujuan untuk mengestimasi dan memprediksi rata-rata populasi atau nilai rata-rata variabel dependen yang ditunjukkan dengan angka koefisien. Adapun koefisien diperoleh dengan cara memprediksi nilai variabel dependen dengan satu persamaan regresi:

Keterangan:

$$
P P K_{i t}=\beta_{0}+\beta_{1} B M_{i t}+\beta_{2} P A D_{i t}+\beta_{3} \mathrm{JP}_{i t}+\varepsilon_{i t}
$$

$$
\begin{array}{ll}
\text { PPK } & =\text { Pendapatan Per Kapita } \\
\text { BM } & =\text { Belanja Modal } \\
\text { PAD } & =\text { Pendapatan Asli Daerah }
\end{array}
$$




$\begin{array}{ll}\text { JP } & =\text { Jumlah Penduduk } \\ \beta_{0} & =\text { Intercept } \\ \beta_{1}-\beta_{3} & =\text { Koefisien Regresi } \\ \mathrm{i} & =\text { Subskrip Tempat } \\ \mathrm{t} & =\text { Subskrip Waktu } \\ \varepsilon & =\text { error term }\end{array}$

4. Uji Hipotesis

Uji hipotesis dalam penelitian ini meliputi uji signifikansi simultan (Uji F), uji signifikansi parsial (Uji t), dan uji koefisien determinan $\left(R^{2}\right)$ yang hasilnya adalah sebagaimana diuraikan berikut ini.

\section{a. Uji F}

Uji $F$ bertujuan untuk menguji apakah semua variabel independen secara serentak bersama-sama (simultan) berpengaruh terhadap variabel dependen. Uji $\mathrm{F}$ digunakan untuk mengetahui model regresi yang digunakan dalam penelitian sudah sesuai atau tidak sesuai (goodness of fit). Pengujian dengan uji $\mathrm{F}$ dilakukan dengan membandingkan antara $F_{\text {hitung }}$ dengan $F_{\text {tabel. }}$. Jika nilai $F_{\text {hitung }}$ lebih kecil dari $F_{\text {tabel, }}$ maka tidak ada pengaruh secara serentak dari semua variabel independen terhadap variabel dependen (model regresi tidak goodness of fit), dan sebaliknya jika nilai $F_{\text {hitung }}$ lebih besar dari $\mathrm{F}_{\text {tabel}}$, maka ada pengaruh secara serentak dari semua variabel independen terhadap variabel dependen (model regresi goodness of fit). Hasil uji juga diihat dari perbandingan antara nilai Sig. $F$ dengan a $(0,05)$. Jika nilai Sig. $F$ lebih besar dari $\alpha$ $(0,05)$, maka tidak ada pengaruh secara serentak dari semua variabel independen terhadap variabel dependen (model regresi tidak goodness of fit), dan sebaliknya jika nilai Sig.F lebih kecil dari a $(0,05)$, maka ada pengaruh secara serentak dari semua variabel independen terhadap variabel dependen (model regresi goodness of fit).

b. Uji t

Uji t bertujuan untuk menguji apakah pengaruh masing-masing variabel independen terhadap variabel dependen. Uji $t$ digunakan untuk menunjukkan dukungan terhadap hipotesis penelitian. Pengujian ini dilakukan dengan membandingkan antara $t_{\text {hitung }}$ dengan $t_{\text {tabel }}$. Jika nilai $t_{\text {hitung }}$ lebih kecil dari $t_{\text {tabel }}$, maka variabel independen tersebut tidak berhubungan secara statistik terhadap variabel dependen, dan sebaliknya jika nilai $t_{\text {hitung }}$ lebih besar dari tabel, maka variabel independen tersebut berhubungan secara statistik terhadap variabel dependen. Hasil uji juga diihat dari perbandingan antara nilai Signifikansi $t$ dengan a $(0,05)$. Jika nilai Signifikansi $t$ lebih besar dari $a$ $(0,05)$, maka variabel independen tersebut tidak berhubungan secara statistik terhadap variabel dependen, dan sebaliknya jika nilai Signifikansi t lebih kecil dari a $(0,05)$, maka variabel 
independen tersebut berhubungan secara statistik terhadap variabel dependen.

c. Uji Koefisien Determinasi $\left(\mathbf{R}^{2}\right)$

Uji $R^{2}$ bertujuan untuk mengukur seberapa jauh kemampuan model dalam menerangkan variasi variabel dependen, yang mana besarnya nilai $R^{2}$ terlihat dalam rentang antara 0 sampai dengan 1. Jika nilai $R^{2}$ mendekati 0 , maka kemampuan variabel-variabel independen dalam menjelaskan variabel dependen sangat terbatas, dan sebaliknya jika nilai $R^{2}$ mendekati 1, maka kemampuan variabel-variabel independen dalam menjelaskan variabel dependen sangat kuat. HASIL

1. Analisis Deskriptif

Hasil statistik deskriptif adalah sebagaimana tercantum pada tabel 1.

Tabel 1. Hasil Analisis Deskriptif

\begin{tabular}{cccccc}
\hline & N & Minimum & Maximum & Mean & Std. Deviation \\
\hline PPK & 49 & 1510,5298 & 3770,3030 & 2268,257724 & 516,3995808 \\
BM & 49 & 141263726 & 553086970 & 327874480,10 & 107536600,169 \\
PAD & 49 & 111592606 & 544781462 & 297731544,98 & 102374727,051 \\
JP & 49 & 507825 & 1171411 & 887573,88 & 182048,152 \\
Valid N & 49 & & & & \\
(listwise) & & & & & \\
\hline
\end{tabular}

Sumber: Data sekunder diolah peneliti, 2020.

Berdasarkan tabel tersebut dapat dilihat nilai mean pendapatan per kapita sebesar 2.268,257724, nilai maksimum sebesar 3.770,3030, nilai minimum sebesar $1.510,5298$, dan nilai standar deviasi sebesar 516,3995808. Nilai mean belanja modal sebesar 327.874.480,10, maksimum sebesar 553.086.970, nilai minimum sebesar 141.263.726, nilai dan nilai standar deviasi sebesar 107.536.600,169. Nilai mean PAD sebesar 297.731.544,98, maksimum sebesar 544.781.462, nilai minimum sebesar 111.592.606, nilai dan nilai standar deviasi sebesar 102.374.727,051. Nilai mean jumlah penduduk sebesar $887.573,88$, nilai maksimum sebesar 1.171.411, nilai minimum sebesar 507.825 , dan nilai standar deviasi sebesar 182.048,152.

2. Uji Asumsi Klasik

a. Uji Normalitas

Hasil uji normalitas dirangkum dalam tabel 2 berikut ini.

Tabel 2. Hasil Uji Normalitas

\begin{tabular}{llr}
\hline & & Unstandardized Residual \\
\hline $\mathrm{N}$ & Mean & 49 \\
Normal Parameters & $0 \mathrm{E}-7$ \\
& Std. Deviation & 187,90897443 \\
& Absolute &, 071 \\
Most Extreme Differences & Positive &, 071 \\
& Negative & -056 \\
Kolmogorov-Smirnov Z & &, 496 \\
Asymp. Sig. (2-tailed) & &, 966 \\
\hline
\end{tabular}


Sumber: Data sekunder diolah peneliti, 2020.

Berdasarkan tabel tersebut dapat diketahui bahwa nilai Kolmogorov-Smirnov $Z(0,496)$ atau nilai signifikansi $(0,966)$ lebih besar dari a $(0,05)$, sehingga residual data yang digunakan dalam penelitian ini terdistribusi normal.

b. Uji Multikolinieritas

Hasil uji multikolinieritas dirangkum dalam tabel 3 berikut ini.

Tabel 3. Hasil Uji Multikolinieritas

\begin{tabular}{llll}
\hline \multicolumn{1}{c}{ Model } & \multicolumn{2}{c}{ Collinearity Statistics } \\
\multicolumn{1}{c}{ (Constant) } & & \\
1 & Tolerance & \\
1 & BM &, 586 & 1,707 \\
& PAD &, 429 & 2,330 \\
JP &, 626 & 1,597 \\
\hline
\end{tabular}

Sumber: Data sekunder diolah peneliti, 2020.

Berdasarkan tabel tersebut dapat diketahui bahwa nilai VIF seluruh variabel independen kurang dari 10, sehingga dapat dikatakan bahwa data yang digunakan dalam penelitian ini tidak terjadi masalah multikolinieritas.

c. Uji Heteroskedastisitas

Hasil uji heteroskedastisitas dirangkum dalam tabel 4 berikut ini.

Tabel 4. Hasil Uji Heteroskedastisitas

\begin{tabular}{llcl}
\hline \multicolumn{1}{c}{ Model } & t & Sig. \\
\hline & (Constant) &,- 211 &, 834 \\
1 & BM & $-1,865$ &, 069 \\
& PAD & 1,578 &, 122 \\
JP & 1,962 &, 056 \\
\hline
\end{tabular}

Sumber: Data sekunder diolah peneliti, 2020.

Berdasarkan tabel tersebut dapat diketahui bahwa nilai signifikansi belanja modal $(0,069)$, PAD $(0,122)$, dan jumlah penduduk $(0,056)$, lebih besar dari $\alpha(0,05)$, sehingga dapat dikatakan bahwa data yang digunakan dalam penelitian ini tidak terjadi heteroskedastisitas.

d. Uji Autokorelasi

Hasil uji autokorelasi dirangkum dalam tabel 5 berikut ini.

Tabel 5. Hasil Uji Autokorelasi

\begin{tabular}{lr}
\hline & Unstandardized Residual \\
\hline Test Value $^{\text {a }}$ & $-11,81109$ \\
Cases $<$ Test Value & 24 \\
Cases $>=$ Test Value & 25 \\
Total Cases & 49 \\
Number of Runs & 20 \\
Z & $-1,441$ \\
Asymp. Sig. (2-tailed) &, 149 \\
\hline Sumber: Data sekunder diolah peneliti, 2020. & \\
Berdasarkan tabel tersebut dapat diketahui & bahwa nilai \\
signifikansi Z atau Asymp. Sig. $(0,149$ lebih besar dari a $(0,05)$,
\end{tabular}


sehingga dapat dikatakan bahwa data yang digunakan dalam penelitian ini tidak terjadi autokorelasi.

Dari hasil uji asumsi klasik tersebut menunjukkan bahwa data yang diambil sesuai untuk dianalisis menggunakan regresi linier berganda.

\section{Analisis Regresi Linier Berganda}

Hasil analisis regresi linear berganda dirangkum dalam tabel 6 berikut ini.

Tabel 6. Hasil Uji Regresi Linier Berganda

\begin{tabular}{|c|c|c|c|c|c|c|}
\hline & Model & $\begin{array}{r}\text { Unstan } \\
\text { Coeff }\end{array}$ & $\begin{array}{l}\text { irdized } \\
\text { ients }\end{array}$ & $\begin{array}{l}\text { Standardized } \\
\text { Coefficients }\end{array}$ & $t$ & Sig. \\
\hline & & B & Std. Error & Beta & & \\
\hline & (Constant) & 2433,363 & 228,481 & & 10,650 &, 000 \\
\hline & BM & 1,092E-006 & ,000 & 227 & 3,208 & ,002 \\
\hline 1 & PAD & $2,360 \mathrm{E}-006$ & ,000 & ,468 & 5,651 & ,000 \\
\hline & $J P$ &,- 001 & ,000 &,- 487 & $-7,102$ & ,000 \\
\hline
\end{tabular}

Sumber: Data sekunder diolah peneliti, 2020.

Dari tabel tersebut dapat disusun persamaan:

$\mathrm{PPK}_{\mathrm{it}}=2433,363+0,000001092 \mathrm{BM}_{\mathrm{it}}+0,000002360 \mathrm{PAD}_{\text {it }}-0,001$ $J P_{i t}+\varepsilon_{i t}$

Konstanta memiliki nilai sebesar $+2433,363$, yang artinya apabila pada saat belanja modal, PAD, dan jumlah penduduk diasumsikan konstanta, maka pendapatan per kapita Kabupaten/Kota Eks Karesidenan Surakarta adalah sebesar 2433,363.

Koefisien belanja modal memiliki nilai sebesar $+0,000001092$. Hal ini berarti apabila belanja modal naik 1 satuan, maka pendapatan per kapita akan meningkat sebesar 0,000001092 satuan, dan sebaliknya apabila belanja modal turun 1 satuan, maka pendapatan per kapita akan berkurang sebesar 0,000001092.

Koefisien PAD memiliki nilai sebesar +0,000002360. Hal ini berarti apabila PAD naik 1 satuan, maka pendapatan per kapita akan meningkat 0,000002360 satuan, dan apabila PAD turun 1 satuan, maka pendapatan per kapita akan berkurang sebesar 0,000002360 satuan.

Koefisien jumlah penduduk memiliki nilai sebesar $-0,001$. Hal ini berarti apabila jumlah penduduk naik 1 satuan, maka pendapatan per kapita akan berkurang sebesar 0,001 satuan, dan sebaliknya apabila jumlah penduduk turun 1 satuan, maka pendapatan per kapita akan meningkat 0,001 satuan.

4. Uji Hipotesis

\section{a. Uji F}

Hasil uji F dirangkum dalam tabel 7 berikut ini.

\begin{tabular}{|c|c|c|c|c|c|c|}
\hline & Model & $\begin{array}{c}\text { Sum of } \\
\text { Squares }\end{array}$ & df & Mean Square & $\mathbf{F}$ & Sig. \\
\hline \multirow{3}{*}{1} & Regression & 11105219,732 & 3 & 3701739,911 & 98,284 &, $000^{b}$ \\
\hline & Residual & 1694869,568 & 45 & 37663,768 & & \\
\hline & Total & 12800089,301 & 48 & & & \\
\hline
\end{tabular}


Sumber: Data sekunder diolah peneliti, 2020.

Berdasarkan tabel tersebut dapat diketahui bahwa nilai $F_{\text {hitung }}$ $(98,284)$ lebih besar dari nilai $F_{\text {tabel }}(2,816)$ dan nilai signifikansi $F(0,000)$ lebih kecil dari a $(0,05)$, sehingga variabel belanja modal, PAD, dan jumlah penduduk secara simultan berpengaruh terhadap variabel pendapatan per kapita, yang berarti model regresi yang digunakan dalam penelitian ini goodness of fit.

b. Uji t

Hasil uji t dirangkum dalam tabel 8 berikut ini.

Tabel 8. Hasil Uji t

\begin{tabular}{llrrrrr}
\hline Model & \multicolumn{2}{c}{$\begin{array}{c}\text { Unstandardized } \\
\text { Coefficients }\end{array}$} & $\begin{array}{c}\text { Standardized } \\
\text { Coefficients } \\
\text { Beta }\end{array}$ & t & Sig. \\
& \multicolumn{1}{c}{ B } & Std. Error & & \\
\hline & (Constant) & 2433,363 & 228,481 & & 10,650 &, 000 \\
BM & $1,092 \mathrm{E}-006$ &, 000 &, 227 & 3,208 &, 002 \\
PAD & $2,360 \mathrm{E}-006$ &, 000 &, 468 & 5,651 &, 000 \\
& JP &,- 001 &, 000 &,- 487 & $-7,102$ &, 000 \\
\hline
\end{tabular}

Sumber: Data sekunder diolah peneliti, 2020.

Variabel belanja modal memiliki hubungan linier-linier (lin-lin) dengan variabel pendapatan per kapita yang diketahui dari nilai $t_{\text {hitung }}(3,208)$ lebih besar dari nilai tabel $(2,014)$ dan nilai signifikansi $(0,002)$ lebih kecil dari a $(0,05)$. Hal ini berarti belanja modal mempunyai pengaruh signifikan terhadap pendapatan per kapita.

Variabel PAD memiliki hubungan linier-linier (lin-lin) dengan variabel pendapatan per kapita yang diketahui nilai $t_{\text {hitung }}(5,651)$ lebih besar dari nilai $t_{\text {tabel }}(2,014)$ dan nilai signifikansi $(0,000)$ lebih kecil dari a $(0,05)$. Hal ini berarti PAD mempunyai pengaruh signifikan terhadap pendapatan per kapita.

Variabel jumlah penduduk memiliki hubungan linier-linier (lin-lin) dengan variabel pendapatan per kapita yang diketahui nilai $t_{\text {hitung }}(7,102)$ lebih besar dari nilai $t_{\text {tabel }}(2,014)$ dan nilai signifikansi $(0,000)$ lebih kecil dari a $(0,05)$. Hal ini berarti jumlah penduduk mempunyai pengaruh signifikan terhadap pendapatan per kapita.

c. Uji Koefisien Determinasi $\left(\mathbf{R}^{2}\right)$

Hasil uji koefisien determinasi dirangkum dalam tabel 9 berikut ini.

Tabel 9. Hasil Uji Koefisien Determinasi $\left(\mathbf{R}^{2}\right)$

\begin{tabular}{ccccc}
\hline Model & $\mathbf{R}$ & $\mathbf{R}$ Square & $\begin{array}{c}\text { Adjusted } \mathbf{R} \\
\text { Square }\end{array}$ & $\begin{array}{c}\text { Std. Error of the } \\
\text { Estimate }\end{array}$ \\
\hline 1 &, $931^{\mathrm{a}}$ &, 868 &, 859 & 194,0715543 \\
\hline
\end{tabular}

Sumber: Data sekunder diolah peneliti, 2020.

Berdasarkan hasil perhitungan nilai $R^{2}$ diperoleh angka sebesar 0,868 yang berarti bahwa $86,8 \%$ variabel pendapatan per kapita dapat dijelaskan oleh variabel belanja modal, PAD, dan 
jumlah penduduk, sedangkan sisanya 13,2\% dijelaskan oleh faktor-faktor lain di luar model yang diteliti.

\section{PEMBAHASAN}

1. Belanja Modal Berpengaruh Terhadap Pendapatan Per Kapita

Belanja modal digunakan untuk sektor-sektor yang dapat meningkatkan pendapatan masyarakat. Alokasi belanja modal tersebut digunakan untuk pengembangan infrastruktur yang dapat mendorong perekonomian, sehingga tingkat produktifitas masyarakat meningkat. Dengan meningkatnya produktifitas masyarakat, maka berdampak meningkatkan pendapatan masyarakat yang tercermin dalam pendapatan per kapita. Dari hasil tersebut, maka penelitian ini sesuai dengan penelitian Purba dan Silalahi (2019).

2. PAD Berpengaruh Terhadap Pendapatan Per Kapita

PAD yang meningkat berasal dari sektor-sektor yang ada di dalam ruang lingkup daerah Kabupaten/Kota Eks Karesidenan Surakarta, sehingga pendapatan yang masuk dan diterima oleh Pemerintah Daerah dapat meningkatkan pendapatan per kapita Kabupaten/Kota Eks Karesidenan Surakarta. Peningkatan PAD yang semakin tinggi akan merangsang pemerintah daerah untuk meningkatkan mutu dan pelayanan terhadap masyarakat, sehingga pendapatan per kapita masyarakat meningkat. Dengan kata lain, daerah dengan pertumbuhan PAD yang positif akan meningkatkan pendapatan per kapita masyarakat dari daerah tersebut. Dari hasil tersebut, maka penelitian ini sesuai dengan penelitian Sumardi (2015), dan Purba dan Silalahi (2019).

3. Jumlah Penduduk Berpengaruh Terhadap Pendapatan Per Kapita

Semakin bertambahnya jumlah penduduk menyebabkan semakin banyak pendapatan yang harus dibagi karena bertambahnya jumlah penduduk. Hal ini relevan dengan Model Pertumbuhan Solow-Swan, yang menyatakan bahwa pertumbuhan penduduk memiliki hubungan negatif dengan tingkat pendapatan per kapita. Model Solow menyatakan bahwa pertumbuhan penduduk akan memengaruhi standar hidup (standard of living) suatu negara yang dicerminkan dalam pendapatan domestik bruto per kapita. Negara-negara dengan pertumbuhan penduduk yang tinggi akan memiliki tingkat pendapatan domestik bruto per kapita yang rendah, dan sebaliknya negara-negara dengan pertumbuhan penduduk yang rendah akan memiliki tingkat pendapatan domestik bruto per kapita yang tinggi. Dari hasil tersebut, maka penelitian ini sesuai dengan penelitian Masniadi (2012).

\section{KESIMPULAN}

Dari hasil analisis data dapat diambil simpulan sebagai berikut: 
1. Belanja modal berpengaruh (secara statistik signifikan) terhadap pendapatan per kapita di Kabupaten/Kota Eks Karesidenan Surakarta tahun 2013-2019. Simpulan ini ditunjukkan dari nilai thitung koefisien regresi $(3,208)$ lebih besar dari nilai $t_{\text {tabel }}(2,014)$ dan/atau nilai signifikansi $(0,002)$ lebih kecil dari a $(0,05)$. Hal ini berarti $\mathrm{H}_{1}$ dalam penelitian ini terdukung.

2. PAD berpengaruh (secara statistik signifikan) terhadap pendapatan per kapita di Kabupaten/Kota Eks Karesidenan Surakarta tahun 2013-2019. Simpulan ini ditunjukkan dari nilai $t_{\text {hitung }}$ koefisien regresi $(5,651)$ lebih besar dari nilai $t_{\text {tabel }}(2,014)$ dan/atau nilai signifikansi $(0,000)$ lebih kecil dari $\alpha(0,05)$. Hal ini berarti $\mathrm{H}_{2}$ dalam penelitian ini terdukung.

3. Jumlah penduduk berpengaruh (secara statistik signifikan) terhadap pendapatan per kapita di Kabupaten/Kota Eks Karesidenan Surakarta tahun 2013-2019. Simpulan ini ditunjukkan dari nilai thitung koefisien regresi $(7,102)$ lebih besar dari nilai $t_{\text {tabel }}(2,014)$ dan/atau nilai signifikansi $(0,000)$ lebih kecil dari $\alpha(0,05)$. Hal ini berarti $\mathrm{H}_{3}$ dalam penelitian ini terdukung.

\section{DAFTAR PUSTAKA}

Badrudin, R. (2011). Ekonomi Otonomi Daerah. Yogyakarta: UPP STIM YKPN Yogyakarta.

Bastian, I. (2006). Akuntansi Sektor Publik. Jakarta: Erlangga.

Buletin Teknis Standar Akuntansi Pemerintahan No. 4 tentang Penyajian dan pengungkapan Belanja Pemerintahan.

Darise, N. (2008). Akuntansi Keuangan Daerah (Akuntansi Sektor Publik). Jakarta: PT Indeks.

Daryanto. (1996). Kependudukan. Bandung: Tarsito.

Ghozali, I. (2011). Aplikasi Analisis Multivariate dengan Program IBM SPSS 19. Edisi Kelima. Semarang: Badan Penerbit Universitas Diponegoro.

Halim, A. (2008). Akuntansi Keuangan Daerah: Edisi Ketiga. Jakarta: Salemba Empat.

Hoesada, J. (2016). Akuntansi Pemerintahan. Jakarta: Salemba Empat.

Kuncoro, M. (2010). Ekonomika Pembangunan : Masalah, Kebijakan, dan Politik. Jakarta: Erlangga.

[Kuncoro, M. (2013). Mudah Memahami dan Menganalisis Indikator Ekonomi. Yogyakarta: UPP STIM.

Mangkoesoebroto, G. (2010). Ekonomi Publik Edisi-III. Yogyakarta: BPFE.

Mankiw, G. N. (2006). Teori Makroekonomi Edisi Keenam. Jakarta: Erlangga.

Masniadi, R. (2012). Analisis Jumlah Penduduk, Tabungan, dan Investasi terhadap Tingkat Pendapatan Perkapita Indonesia. Jurnal Ekonomi Pembangunan, Vol 10 No. 1, 68-80.

Nugroho, F., \& Rohman, A. (2012). Pengaruh Belanja Modal Terhadap Pertumbuhan Kinerja Keuangan Daerah Dengan Pendapatan Asli 
Daerah Sebagai Variabel Intervening (Studi Kasus Di Propinsi Jawa Tengah). Diponegoro Journal Of Accounting Vol 1 No 2, 1-14.

Peraturan Pemerintah Republik Indonesia Nomor 24 Tahun 2005 tentang Standar Akuntansi Pemerintahan.

Permendagri No. 13 Tahun 2006 tentang Pedoman Pengelolaan Keuangan Daerah .

Purba, S., \& Silalahi, M. (2019). Pengaruh Belanja Modal Pendapatan Asli Daerah dan Dana Perimbangan terhadap Pendapatan Perkapita Pada Pemerintah Kabupaten/Kota Provinsi Riau. Jurnal IImiah Simantek, 1-10.

Renyowijoyo, M. (2008). Akuntansi Sektor Publik Non Laba. Jakarta: Mitra Wacana Media.

Subagiarta, I. W. (2006). Sumber Daya Manusia. Jember: FE UNEJ.

Sumardi. (2015). Analisis Pendapatan Asli Daerah, Dana Alokasi Umum, dan Dana Alokasi Khusus terhadap Pendapatan Per Kapita Pada Kabupaten/Kota Di Provinsi Bali. Jurnal Akses, Vol. 25 No.2, 3-23.

Suryani. (2015). Metode Riset Kuantitatif Teori dan Aplikasi pada Peneliian Bidang Manajemen dan Ekonomi Islam. Jakarta: PT. Fajar Interpratama Mandiri.

Undang-Undang No. 22 Tahun 1999 tentang Pemerintah Daerah.

Undang-Undang No. 25 Tahun 1999 tentang Perimbangan Keuangan.

Undang-Undang No. 32 Tahun 2004 tentang Pemerintah Daerah.

Undang-Undang No. 33 Tahun 2004 tentang Perimbangan Keuangan. 